\title{
Adrenal nodule visualised on adrenal vein catheterisation
}

\author{
Queenie Guinto Ngalob, Frances Lina Lantion-Ang
}

Section of Endocrinology, Diabetes and Metabolism, Department of Medicine, University of the Philippines, Philippine General Hospital, Manila, Philippines

\section{Correspondence to}

Dr Queenie Guinto Ngalob, queenngalob@yahoo.com
CrossMark

To cite: Ngalob QG,

Lantion-Ang FL. BMJ Case Rep Published online: [please include Day Month Year] doi:10.1136/bcr-2013200149

\section{DESCRIPTION}

A 36-year-old man underwent adrenal vein catheterisation to investigate the aetiology of hypertension. He had resistant hypertension as high as 220/ 120 despite three oral medications. He had recurrent lower extremity weakness with documented hypokalaemia as low as $2.1 \mathrm{mmol} / \mathrm{L}$. A diagnosis of primary aldosteronism (PA) was made based on unsuppressed aldosterone of $27.7 \mathrm{ng} / \mathrm{dL}$ after $2 \mathrm{~L}$ of saline solution was given intravenously. A CT scan revealed a $1.1 \times 1.5 \times 1.3 \mathrm{~cm}$ well-defined hypodense nodule in the lateral limb of the right adrenal, while the left adrenal was normal. This was suggestive of an aldosterone-producing adenoma (APA). As recommended by Endocrine Society, an adrenal vein sampling (AVS) was conducted to confirm the laterality of aldosterone excess and establish the diagnosis of an APA. Angiography of the right adrenal vein of the patient demonstrated circular configuration of the veins surrounding a round structure consistent with a nodule (figure 1). Blood sampling yielded lateralised aldosterone excess to the right (selectivity index $>2$ and lateralisation index $=5.74$ ) consistent with an APA.

AVS is an invasive procedure employed to establish the subtype of PA. The Endocrine Society recommends that when surgery is practicable and desired, AVS should be conducted after an adrenal CT scan to establish laterality of aldosterone excess. The absence of laterality is seen in bilateral adrenal hyperplasia for which treatment is medical. Lateralisation is seen in APA or unilateral adrenal hyperplasia for which adrenalectomy is indicated. ${ }^{1}$ On fluoroscopic image, the adrenal veins adopt a circular configuration to surround the tumour.

\section{Learning points}

- Adrenal vein catheterisation and sampling are essential to establish the subtype of primary aldosteronism. It influences treatment decisions.

- The benefit of adrenal vein sampling lies in establishing laterality of aldosterone excess. Lateralisation is seen in aldosterone-producing adenoma for which adrenalectomy may be curative.

- In adrenal adenomas, adrenal veins adopt a circular configuration and this may be seen on venography.

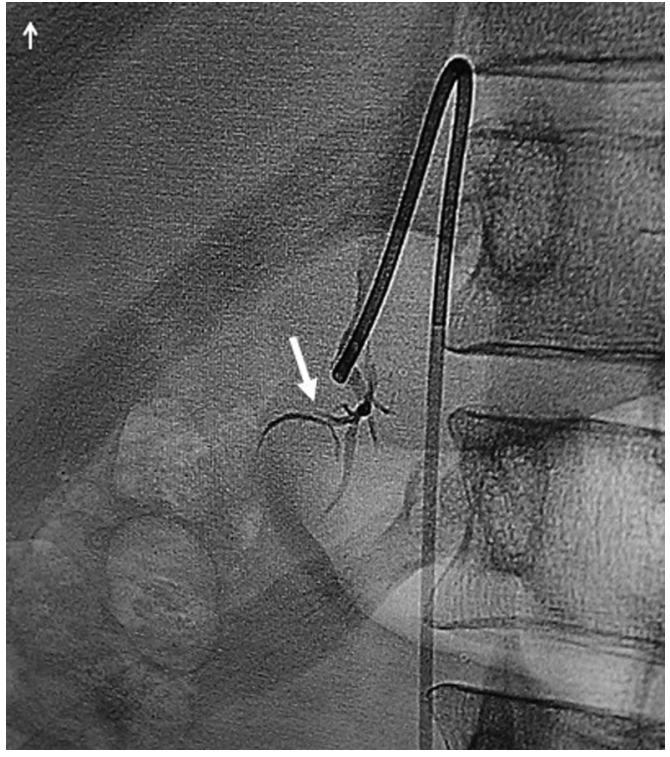

Figure 1 Right adrenal venogram demonstrated circular configuration of the veins surrounding a round structure consistent with a nodule (arrow).

\section{Competing interests None.}

Patient consent Obtained.

Provenance and peer review Not commissioned; externally peer reviewed.

\section{REFERENCE}

1 Funder JW, Carey RM, Fardella C, et al. Case detection, diagnosis, and treatment of patients with primary aldosteronism: an Endocrine Society Clinical Practice Guideline. J Clin Endocrinol Metab 2008:93:3266-81. 
Copyright 2013 BMJ Publishing Group. All rights reserved. For permission to reuse any of this content visit http://group.bmj.com/group/rights-licensing/permissions.

BMJ Case Report Fellows may re-use this article for personal use and teaching without any further permission.

Become a Fellow of BMJ Case Reports today and you can:

- Submit as many cases as you like

- Enjoy fast sympathetic peer review and rapid publication of accepted articles

- Access all the published articles

- Re-use any of the published material for personal use and teaching without further permission

For information on Institutional Fellowships contact consortiasales@bmjgroup.com

Visit casereports.bmj.com for more articles like this and to become a Fellow 